\title{
Reaction of Dry Bean Genotypes to Natural Infection of Foliar Diseases in the Dominican Republic, ${ }^{1,2}$
}

\author{
James S. Beaver, César V. Paniagua, James R. Steadman, and \\ Rodrigo Echávez-Badel ${ }^{3}$
}

\begin{abstract}
Seventeen dry bean genotypes were tested in 18 field trials on small farms and experiment stations in the Dominican Republic in the 1981-1982 growing season, and 20 bean genotypes were tested in 10 trials in the 1982-1983 growing season to measure the reaction of promising dry bean genotypes and standard cultivars from the Dominican Republic to natural infection of foliar diseases, and to determine the frequency and intensity of foliar diseases when dry beans are generally grown in the Dominican Republic. Bacterial blight [Xanthomonas campestris pr. phaseoli (Smith) Dye] was the most serious disease during the September plantings. Rust [Uromyces phaseoli (Reben) Wint.] was the most prevalent disease when beans were planted in January, which is a drier month. There was little difference among the dry bean genotypes in reaction to bacterial blight. All of the genotypes developed at least a moderate level of infection of bacterial blight following the September plantings. However, several genotypes expressed high levels of resistance to rust. Among the standard red mottled cultivars, Pompadour developed the lowest level of rust infection. Angular leaf spot (/sariopsis griseola Sacc.) and chaetoseptoria leaf spot (Chaetoseptoria wellmanii Stevenson) also were observed in several experiments. One genotype, 5B-42-2-1, expressed a low level of infection to angular leaf spot having an average score of 1.5 , whereas all genotypes were found to be susceptible to chaetoseptoria leaf spot.
\end{abstract}

\section{INTRODUCTION}

Diseases are among the most important factors contributing to the low and erratic seed yields of dry beans (Phaseolus vulgaris L.) in Latin American countries such as the Dominican Republic. ${ }^{4,5}$ Researchers in the Dominican Republic recently initiated a dry bean breeding program to develop disease resistant cultivars adapted to local conditions. To be

${ }^{1}$ Manuscript submitted to Editorial Board September 4, 1984.

${ }^{2}$ The research was supported in part by Title XII Bean/Cowpea CRSP of the U.S. Agency for International Development under Grant No. AID/DSAN/XII-G-0251 and assigned paper number 7549, J. Ser., Nebr. Agric. Exp. Stn. under project 20-036.

${ }^{3}$ Assistant Professor, Department of Agronomy and Soils, University of Puerto Rico, Mayagüez, P.R. 00708; Principal Investigator, Title XII Bean/Cowpea Project, Secretaría de Estado de Agricultura, Arroyo Loro Experiment Station, San Juan de la Maguana, República Dominicana; Associate Professor, Department of Plant Pathology, University of Nebraska, Lincoln, NE 69503; and Assistant Investigator, Department of Crop Protection, University of Puerto Rico, Mayagüez, P.R. 00708

${ }^{4}$ Anonymous, 1979. Perspectivas sobre la producción de leguminosas alimenticias en la República Dominicana. Secretaría de Estado de Agricultura, Santo Domingo, Repüblica Dominicana.

${ }^{5}$ Schieber, E., 1970. Enfermedades del frijol (Phaseolus vulgaris L.) en la República Dominicana, Turrialba 20 (1):20-3. 
successful, researchers need to identify dry bean germplasm with resistance to the diseases most prevalent in the Dominican Republic. Because certain dry bean diseases such as rust [Uromyces phaseoli (Reben) Wint.] develop different pathogenic races, promising germplasm should be screened for resistance to the races present in the bean growing region. Moreover, climatic conditions greatly influence frequency and intensity of dry bean diseases. Because temperature and rainfall patterns vary with the season, promising germplasm should be tested when dry beans are most commonly grown. Therefore, the objectives of this research were 1) to compare the reaction of a group of promising dry bean genotypes with a group of standard cultivars from the Dominican Republic under natural infection of foliar diseases, and 2) to measure the frequency and intensity of foliar diseases during the periods when dry beans are generally grown in the Dominican Republic.

\section{MATERIALS AND METHODS}

Seventeen dry bean genotypes were tested in 18 field trials in small farms and experiment stations in the Dominican Republic during the 1981-1982 growing season and 20 bean genotypes were tested in 10 trials during the 1982-1983 growing season. The trials included breeding lines from Puerto Rico, the University of Nebraska, and CIAT, which were considered to be of potential value to the bean breeding program in the Dominican Republic. In addition, the trials included four standard cultivars from the Dominican Republic, which were used as checks. The four standard cultivars were the red-mottled lines Agricultor, José Beta and Pompadour, and the black seeded line Venezuela 44.

The experimental design in the 1981-1982 growing season was a splitplot arrangement of a randomized complete block. The whole plots consisted of a fertilized and an unfertilized treatment. Granular fertilizer was used in the fertilizer treatment. However, the formula rate, and mode of application varied depending upon the practices of the cooperating farmers. The split-plot consisted of the dry bean genotypes. Each treatment combination was replicated twice. Experimental units consisted of single rows $2.5 \mathrm{~m}$ long. Spacing between rows varied between 40 and 45 $\mathrm{cm}$, and 25 seeds were planted in each row. A randomized complete block design was used in the 1982-1983 growing season. The treatments were the 20 bean genotypes and each treatment was replicated four times. Size of the experimental units and cultural practices were the same as those used during the 1981-1982 growing season. Fertilizer was used on trials planted in farms that fertilized beans. As during the previous growing season, the formula, rate, and mode of application varied depending upon practices of the cooperating farmers. 
Genotypes were rated for natural infection of the foliar diseases most prevalent in the trial. Disease notes were limited to those locations where appreciable levels of infection had occurred. As a consequence, ratings for certain diseases were not conducted at all locations. Bacterial blight [Xanthomonas campestris pr. phaseoli (Smith) Dye], angular leaf spot (Isoriopsis griseola Sacc.), and chaetoseptoria leaf spot (Chaetoseptoria wellmanii Stevenson) were rated on a scale from 1 to 5 , with 1 showing no symptoms and 5 showing severe infection. Rust infection was measured by estimating pustule size and percentage of leaf area infected with rust. Pustule size was rated on a scale from 1 to 5 , with 1 having no pustule and 5 having pustules greater than $500 \mu \mathrm{m}$ in diameter. Genotypes were rated for bacterial blight symptoms 40 to 50 days after emergence, whereas rust scores were taken 60 to 70 days after emergence.

\section{RESULTS AND DISCUSSION}

As a group, the red mottled lines from the Dominican Republic bloomed and reached harvest maturity earlier than most genotypes in the test (table 1). Genotypes 5B-42-2-1 and 4M-99 were among the last to flower in 1981-1982, whereas ICA Pijao, L226-10, and L227-1 were among the last to flower in 1982-1983.

The fertilizer treatment had no significant effect on disease scores in 1981-1982. Therefore, the values presented in tables 2, 3, and 4 for 19811982 are averages over both levels of fertility.

Schieber ${ }^{5}$ found bacterial blight to be one of the most serious diseases to affect dry bean production in the Dominican Republic. The September plantings are considered particularly vulnerable to bacterial blight because of the hot and humid conditions during that growing season (table 2). Nevertheless, average bacterial blight infection for the November 1982 and the January 1983 plantings were almost equal to those of the September plantings. ICA Pijao and L226-10 had bacterial blight scores smaller than equal to the means of the plantings. However, these lines are among the latest to mature. Because bacterial blight scores tend to increase as maturity approaches, the low scores of ICA Pijao and L22610 might be more of a reflection of late maturity than of their tolerance or resistance to bacterial blight. EP-1 Pinto had been found to have moderate levels of resistance to bacterial blight in Nebraska. ${ }^{6}$ However, the virulence of the strains-Xanthomonas phaseoli (E. F. Sm.) Dows.in the Dominican Republic or, perhaps, poor adaptation of EP-1 Pinto to environmental conditions in the Dominican Republic did not permit its resistance to be expressed. In general, there was little variability among genotypes for field reaction to bacterial blight.

${ }^{6}$ D. P. Coyne, personal communication. 
TABLE 1.- Seed coat color, growth habit, mean number of days from emergence to initiation of flowering of the dry bean genotypes grown in the Dominican Republic

\begin{tabular}{|c|c|c|c|c|}
\hline \multirow{2}{*}{ Genotype } & \multirow{2}{*}{$\begin{array}{l}\text { Seed coat } \\
\text { color }\end{array}$} & \multirow{2}{*}{$\begin{array}{c}\text { Growth }^{1} \\
\text { habit }\end{array}$} & \multicolumn{2}{|c|}{ Days to first flower } \\
\hline & & & 1981-1982 & $1982-1983$ \\
\hline Agricultor & Red, mottled & 1 & 41 & 37 \\
\hline José Beta & Red, mottled & 1 & 39 & \\
\hline Pompadour & Red, mottled & 1 & 38 & 35 \\
\hline AL-26 & Red, mottled & 2 & & 36 \\
\hline BAT 1274 & Red, mottled & 2 & & 38 \\
\hline EP-1 Pinto & Pinto & 2 & 39 & \\
\hline Venezuela 44 & Black & 2 & 45 & 43 \\
\hline B-190 & Black & 2 & 45 & 44 \\
\hline $3 \mathrm{~B}-76$ & Black & 2 & 45 & 43 \\
\hline $5 B-42-2-1$ & Black & 2 & 47 & \\
\hline La Vega & Black & 2 & 44 & 42 \\
\hline Mexico 309 & Black & 2 & 45 & 45 \\
\hline BAT 271 & Black & 2 & 46 & \\
\hline $2 \mathrm{~B}-5-1$ & Black & 2 & 43 & 42 \\
\hline Porrillo Sintético & Black & 2 & & 44 \\
\hline ICA Pijao & Black & 2 & & 49 \\
\hline BAC 93 & Black & 2 & & 44 \\
\hline Ecuador 299 & Red & 3 & 42 & 40 \\
\hline $2 W-33-2$ & White & 2 & 45 & 42 \\
\hline W-117-2 & White & 2 & 45 & \\
\hline $4 W-44$ & White & 2 & 46 & \\
\hline Blanca del País & White & 2 & & 42 \\
\hline L226-10 & White & 2 & & 43 \\
\hline L227-1 & White & 2 & & 47 \\
\hline L262-2 & White & 2 & & 46 \\
\hline $3 \mathrm{M}-150$ & Red kidney & 1 & 36 & \\
\hline $4 \mathrm{M}-99$ & Brown & 2 & 48 & \\
\hline Mean & & & 43 & 42 \\
\hline L.S.D. (0.05) & & & 1.4 & 1.7 \\
\hline
\end{tabular}

${ }^{1} 1=$ Determinate; 2 = indeterminate small vine; and $3=$ indeterminate large vine.

Planting date appeared to have no effect on the most frequent pustule size of rust (table 3). Although none of the genotypes expressed an immune reaction to rust at all planting dates, several genotypes had most frequent pustule ratings of three or less. The September 1981 planting tended to have the largest pustule sizes.

Percent leaf area infected with rust ranged from $2 \%$ for the September 1982 planting to $20 \%$ for the January 1982 plantings when averaged over all genotypes (table 4). Rust tends to be most severe during the winter, when cooler and dryer conditions prevail. The standard black seeded cultivar in the Dominican Republic, Venezuela 44, was found to be susceptible to rust. On the other hand, the standard red mottled cultivars 
TABLE 2.-Bacterial blight [Xanthomonas campestris pr. (Smith) Dye] scores ${ }^{1}$ of dry bean genotypes grown in the Dominican Republic during the 1981-1982 and 1982-1983 growing seasons

\begin{tabular}{|c|c|c|c|c|c|c|}
\hline \multirow{2}{*}{ Genotype } & \multicolumn{6}{|c|}{ Month planted } \\
\hline & Sept. 81 & Sept. 82 & Nov. 82 & Jan. 82 & Jan. 83 & Apr. 82 \\
\hline Agricultor & 3.6 & 2.7 & 2.6 & 1.3 & 2.7 & 1.1 \\
\hline José Beta & 3.3 & & & 1.5 & & 1.2 \\
\hline Pompadour & 3.3 & 3.2 & 2.9 & 1.4 & 2.6 & 1.0 \\
\hline AL-26 & & 3.0 & 3.3 & & 3.2 & \\
\hline BAT 1274 & & 2.6 & 2.6 & & 2.8 & \\
\hline EP-1 Pinto & 3.4 & & & 1.2 & & 1.1 \\
\hline Venezuela 44 & 3.5 & 3.3 & 2.8 & 1.2 & 2.7 & 1.1 \\
\hline B-190 & 3.5 & 3.3 & 2.9 & 1.3 & 3.4 & 1.1 \\
\hline $3 \mathrm{~B}-76$ & 3.4 & 2.9 & 2.9 & 1.3 & 2.7 & 1.0 \\
\hline $5 \mathrm{~B}-42-2-1$ & 3.6 & & & 1.3 & & 1.0 \\
\hline La Vega & 3.6 & 2.9 & 3.1 & 1.2 & 3.3 & 1.0 \\
\hline Mexico 309 & 3.6 & 3.4 & 2.8 & 1.3 & 3.3 & 1.3 \\
\hline BAT 271 & 3.2 & & & 1.2 & & 1.1 \\
\hline $2 B-5-1$ & 3.5 & 3.1 & 3.0 & 1.5 & 3.4 & 1.2 \\
\hline Porrillo Sintético & & 3.3 & 2.9 & & 2.7 & \\
\hline ICA Pijao & & 2.4 & 2.3 & & 2.6 & \\
\hline BAC 93 & & 3.0 & 2.4 & & 3.1 & \\
\hline Ecuador 299 & 3.5 & 3.1 & 2.8 & 1.5 & 3.0 & \\
\hline $2 W-33-2$ & 3.7 & 2.6 & 3.0 & 1.3 & 2.8 & 1.2 \\
\hline W $117-2$ & 3.4 & & & 1.2 & & 1.1 \\
\hline $4 W-44$ & 3.3 & & & 1.2 & & 1.1 \\
\hline Blanca del País & & 3.1 & 3.3 & & 2.8 & \\
\hline L226-10 & & 2.8 & 2.1 & & 3.0 & \\
\hline L227-1 & & 3.2 & 2.7 & & 2.5 & \\
\hline L262-2 & & 3.1 & 2.3 & & 2.9 & \\
\hline $3 \mathrm{M}-150$ & & 2.6 & 3.6 & & 2.4 & \\
\hline $4 \mathrm{M}-99$ & 3.3 & & & 1.2 & & 1.1 \\
\hline Mean & 3.4 & 3.0 & 2.8 & 1.3 & 2.9 & 1.1 \\
\hline L.S.D. $(0.05)$ & 0.3 & 0.4 & 0.4 & N.S. & 0.4 & N.S. \\
\hline
\end{tabular}

${ }^{1}$ Based on a scale from 1 to 5 , with 1 showing no infection and 5 showing severe infection.

José Beta and Pompadour tended to be resistant, having small pustule sizes and low levels of infection with rust. Black seeded genotypes BAT 1274, B-190, Mexico 309, 2B-5-1 and BAC 93, and white seeded genotypes L226-10, L227-1 and L262-2 had small pustules combined with less than $5 \%$ of leaf area infected with rust. Crosses between the most resistant black seeded genotypes and Venezuela 44 have been made in an attempt to incorporate rust resistance into a plant and seed type similar to Venezuela 44.

Although rust and bacterial blight were the most serious foliar diseases, other diseases were sufficiently severe to merit ratings at certain loca- 
TABLE 3.-The most frequent and the largest rust [Uromyces phaseoli (Reben) Wint.] pustules ${ }^{1}$ observed on dry bean genotypes grown in the Dominican Republic during the 1981-1982 and 1982-1983 growing seasons

\begin{tabular}{|c|c|c|c|c|c|c|c|c|c|c|c|c|}
\hline \multirow{3}{*}{\begin{tabular}{|c|} 
Genotype \\
Agricultor
\end{tabular}} & \multicolumn{12}{|c|}{ Month planted } \\
\hline & \multicolumn{2}{|c|}{ Sept. 81} & \multicolumn{2}{|c|}{ Sept. 82} & \multicolumn{2}{|c|}{ Nov. 82} & \multicolumn{2}{|c|}{ Jan. 82} & \multicolumn{2}{|c|}{ Jan. 83} & \multicolumn{2}{|c|}{ Apr. 82} \\
\hline & $5^{2}$ & $5^{3}$ & 3 & 3 & 3 & 3 & 3 & 5 & 3 & 4 & 1 & 3 \\
\hline José Beta & 4 & 5 & & & & & 3 & 4 & & & 2 & 3 \\
\hline Pompadour & 4 & 5 & 3 & 3 & 3 & 3 & 2 & 4 & 3 & 5 & 2 & 2 \\
\hline $\mathrm{AL}-26$ & & & 3 & 3 & 3 & 3 & & & 3 & 4 & & \\
\hline BAT 1274 & & & 1 & 3 & 3 & 3 & & & 1 & 4 & & \\
\hline EP-1 Pinto & 4 & 5 & & & & & 4 & 5 & & & & \\
\hline Venezuela 44 & 4 & 5 & 3 & 3 & 3 & 4 & 4 & 5 & 5 & 5 & 5 & 5 \\
\hline B-190 & 4 & 4 & 2 & 2 & 2 & 3 & 2 & 3 & 1 & 5 & 2 & 3 \\
\hline $3 \mathrm{~B}-76$ & 3 & 5 & 3 & 3 & 3 & 4 & 4 & 5 & 5 & 5 & 1 & 5 \\
\hline $5 B-42-2-1$ & 5 & 5 & & & & & 5 & 5 & & & 5 & 5 \\
\hline La Vega & 5 & 5 & 3 & 3 & 2 & 3 & 4 & 5 & 3 & 5 & 1 & 5 \\
\hline Mexico 309 & 1 & 5 & 2 & 3 & 2 & 2 & 2 & 2 & 1 & 3 & 2 & 2 \\
\hline BAT 271 & 1 & 5 & & & & & 3 & 3 & & & 2 & 3 \\
\hline $2 B-5-1$ & 1 & 4 & 1 & 4 & & & 1 & 5 & 3 & 5 & 2 & 3 \\
\hline Porrillo Sintético & & & 3 & 3 & & & & & 5 & 5 & & \\
\hline ICA Pijao & & & 1 & 3 & 3 & 4 & & & 3 & 5 & & \\
\hline BAC 93 & & & 2 & 2 & 3 & 4 & & & 1 & 4 & & \\
\hline Ecuador 299 & 4 & 5 & 1 & 3 & 2 & 3 & 3 & 4 & 3 & 4 & & \\
\hline $2 W-33-2$ & 1 & 5 & 1 & 3 & 2 & 2 & 3 & 3 & 3 & 4 & 3 & 3 \\
\hline W 117-2 & 4 & 5 & & & 3 & 3 & 4 & 5 & & & 4 & 5 \\
\hline $4 W-44$ & 1 & 5 & & & & & 4 & 5 & & & 3 & 4 \\
\hline Blanca del País & & & 1 & 4 & 3 & 3 & & & 5 & 5 & & \\
\hline L226-10 & & & 2 & 2 & 2 & 2 & & & 3 & 3 & & \\
\hline L227-1 & & & 2 & 3 & 2 & 2 & & & 1 & 3 & & \\
\hline L262-2 & & & 3 & 3 & 3 & 3 & & & 3 & 4 & & \\
\hline $3 \mathrm{M}-150$ & & & 1 & 4 & & & & & 3 & 4 & & \\
\hline $4 \mathrm{M}-99$ & 1 & 5 & & & & & 2 & 4 & & & 2 & 3 \\
\hline
\end{tabular}

${ }^{1}$ Based on a scale from 1 to 5 , with 1 having no pustules and 5 having pustules greater than $500 \mu \mathrm{m}$ in diameter.

${ }^{2}$ The most frequent rust pustule size observed on a genotype during a particular planting date.

${ }^{3}$ The largest rust pustule size observed on a genotype during a particular planting date.

tions. Angular leaf spot was most severe during the September plantings. Genotypes were rated for reaction to angular leaf spot at five locations. Mean scores of locations ranged from 1.2 to 4.3. Genotype 5B-42-2-1 expressed the lowest level of infection with an average score of 1.5 . Reaction to chaetoseptoria leaf spot was rated at four locations. Mean scores of locations ranged from 3.0 to 4.6. All genotypes tested were found to be susceptible to the chaetoseptoria leaf spot. The incidence of bean golden mosaic was sufficiently severe at only one location to merit 
TABLE 4.-Percent leaf area infected with rust-Uromyces phaseoli (Reben) Wint.-of dry bean genotypes grown in the Dominican Republic during the 1981-1982 and the 19821983 growing seasons

\begin{tabular}{|c|c|c|c|c|c|c|}
\hline \multirow{2}{*}{ Genotype } & \multicolumn{6}{|c|}{ Month planted } \\
\hline & Sept. 81 & Sept. 82 & Nov. 82 & Jan. 82 & Jan. 83 & Apr. 82 \\
\hline Agricultor & 14 & 3 & 7 & 17 & 3 & 5 \\
\hline José Beta & 5 & & & 15 & & 4 \\
\hline Pompadour & 1 & 3 & 10 & 8 & 6 & 2 \\
\hline $\mathrm{AL}-26$ & & 5 & 45 & & 17 & \\
\hline BAT 1274 & 15 & 1 & 3 & & 0 & \\
\hline EP-1 Pinto & 22 & & & 62 & & \\
\hline Venezuela 44 & 1 & 4 & 22 & 43 & 17 & 13 \\
\hline B-190 & 18 & 1 & 3 & 3 & 1 & 2 \\
\hline $3 \mathrm{~B}-76$ & 10 & 2 & 9 & 32 & 10 & 14 \\
\hline $5 \mathrm{~B}-42-2-1$ & 5 & & & 33 & & 12 \\
\hline La Vega & 0 & 2 & 3 & 23 & 7 & 11 \\
\hline Mexico 309 & 1 & 2 & 2 & 2 & 0 & 2 \\
\hline BAT 271 & 0 & & & 7 & & 3 \\
\hline $2 B-5-1$ & & 2 & & 4 & 0 & 3 \\
\hline Porrillo Sintético & & 10 & 21 & & 26 & \\
\hline ICA Pijao & & 2 & 13 & & 5 & \\
\hline BAC 93 & & 1 & 2 & & 3 & \\
\hline Ecuador 299 & 4 & 1 & 3 & 33 & 10 & \\
\hline $2 W-33-2$ & 0 & 1 & 3 & 13 & 7 & 6 \\
\hline W 117-2 & 24 & & & 36 & & 10 \\
\hline $4 W-44$ & 3 & & & 20 & & 6 \\
\hline Blanca del Pais & & 3 & 14 & & 22 & \\
\hline L226-10 & & 1 & 2 & & 1 & \\
\hline L226-1 & & 1. & 2 & & 1 & \\
\hline L262-2 & & 2 & 4 & & 3 & \\
\hline $3 \mathrm{M}-150$ & & 1 & & & 10 & \\
\hline 4M-99 & 0 & & & 8 & & 4 \\
\hline Mean & 8 & 2 & 9 & 20 & 8 & 7 \\
\hline L.S.D. $(0.05)$ & 11.6 & 6.4 & 9.1 & $y .2$ & 4.1 & N.S. \\
\hline
\end{tabular}

ratings for the disease. Nevertheless, the importance of bean golden mosaic virus (BGMV) as a serious disease was illustrated because all genotypes were severely infected with BGMV and seed yields were negligible.

Results of this research provide a base of information of potential value to the bean breeding program in the Dominican Republic. These field trials also were used to estimate seed yields and yield stability characteristics of the bean genotypes. This information, combined with disease reaction data, should enable researchers in the Dominican Republic to be more effective in determining the most appropriate use of these genotypes in their breeding program. In fact, results from this 
study already have contributed in the consideration of the release of the white seeded line 2W-33-2 as a cultivar for the Dominican Republic.

\section{RESUMEN}

En la época de siembra de la habichuela se establecieron 18 ensayos de campo en fincas pequeñas y en estaciones experimentales de la República Dominicana en 1981-1982. Cada experimento de 1981-82 incluyó 17 genotipos. En 1982-1983 se sembraron 10 ensayos con 20 genotipos en cada uno. Los objectivos de esta investigación fueron evaluar la resistencia a enfermedades foliares de un grupo de genotipos prometedores y cultivares corrientes de la República Dominicana y determinan la frecuencia e intensidad de las enfermedades en la época en que mayormente se siembra la habichuela en la República Dominicana. La incidencia más alta de tizón bacteriano-[Xanthomonas campestris pr. phaseoli (Smith) Dye]-ocurrió en la siembra de septiembre. Uromyces phaseoli (Reben) Wint. causó la enfermedad más prevaleciente cuando la habichuela se sembró en enero, el mes más seco. Hubo poca diferencia entre índices de enfermedad en los genotipos afectados por el tizón bacteriano. Sin embargo, todos los genotipos sembrados en septiembre presentaron un nivel moderado de tizón bacteriano. Además, varios genotipos resultaron altamente resistentes a la roya. Entre las variedades corrientes moteadas de color rojo, la Pompadour mostró la incidencia más baja de roya. En varios experimentos también hubo alguna incidencia de mancha angular (Isariopsis griseola Sacc.) y mancha redonda (Chaetoseptoria wellmanii Stevenson). El genotipo 5B-42-2-1 presentó la incidencia más baja de mancha angular (1.5). Sin embargo, todos los genotipos fueron susceptibles a C. wellmanii. 